\title{
4-6 ÉVES ÓVODÁSOK SZOCIÁLIS KÉPESSÉGEINEK FEJLESZTÉSI LEHETŐSÉGEI ÉLMÉNYPEDAGÓGIAI TEVÉKENYSÉGEK ÁLTAL
}

\section{THE ROLE OF EXPERIMENTAL ACTIVITIES IN FACILITATING THE SOCIAL SKILLS OF 4-6 YEAR OLD PRESCHOOL CHILDREN}

\author{
Kovács Réka Mária, Péter Lilla
}

\begin{abstract}
Our paper deals with the possibilities of the social competence development of preschool-aged children. The social competence is a complex, multidimensional concept. The theoretical part of the study discusses the concept and the efficiency of the experimental pedagogical activities and games in the development of school-aged children. In the second part of this studywe present partial results of our research. The primordial question of our research is if the experimental pedagogical activities and games could be efficient in the social competence development of preschool-aged children. Our results demonstrate the efficiency of our research experiment.
\end{abstract}

Keywords: experimental pedagogical activities and games, social competence, preschool children

\section{Bevezető gondolatok}

Napjainkban a szociális kompetencia fejlesztésének szükségessége ismét felerősödött, ugyanis gyermeknek, felnőttnek egyaránt nehézséget okozhat a társas kapcsolatok alakítása és fenntartása, a társakkal való kapcsolattartás. Éppen ezért kutatásunkban 4-6 éves óvodások szociális képességeinek fejlesztését tüztük ki célul. A szociális kompetencia egyike a legösszetettebb és legszerteágazóbb kompetenciánknak. Fejlődését számtalan tényező befolyásolja, főleg gyermekkorban alakul és alakítható. Ezirányú kutatások arra világítanak rá, hogy a szociális kompetencia fejlődésében három nagy tényezőcsoport játszik szerepet, ezek: a személyiségből fakadó, a családi és az óvodai/iskolai tényezők (Konta és Zsolnai, 2002). A kisgyermekkori óvodáskori szocializáció színtere a család, így az anya-gyermekkötődés, a családban kialakult érzelmi kapcsolatok, a szülöi minták és értékek, a szülők szociális kompetenciája, a szülők nevelési stílusa, illetve egyéb szocioökonómiai mutatók, családszerkezet és a családi életmód egyéb tényezői is befolyásolják (Lazsádi, 2017). Emellett óvodáskorban az óvodai nevelés és légkör tényezői a kortársakkal való kapcsolat, a csoportban való népszerűség is hatással vannak.

A szociális kompetencia, Nagy J. kompetenciamodellje alapján, egyike az négy alapkompetenciának. Az egyén szociális kölcsönhatásainak, a szociális környezettel való együttélésének eredményes, hatékony megvalósítása (Nagy, 2000). A szociális kompetenciának már az 1970-es évektől számtalan meghatározása jelent meg, különféle oldalról vizsgálták/határozták meg a szociális kompetenciát, az összetevőit. A szociális kompetencia meghatározásának három korai iránya a szociális kompetenciát a szociális kapcsolatokban megnyilvánuló viselkedés (Argyle, 1983; Trower, 1982 idézi Zsolnai és Józsa, 2002, 12), a 
szociális problémamegoldó gondolkodás (D’Zurilla és Goldfried, 1971; Spivack és Shure, 1976 idézi Zsolnai, 2010, 80), illetve a társas kapcsolatokban megnyilvánuló érzelmek (Rinn és Markle, 1979 idézi Zsolnai, 2010, 81) oldaláról közelítették meg. Ezeket egészítették ki, szintetizálták a szociális kompetencia integratív megközelítései, amelyek közül magyar vonatkozásban a Nagy J. kompetenciamodellje az egyik legismertebb, ezért kutatásunk elméleti megalapozásához ezt vettük figyelembe. A szociális kompetencia összetevői közt a szociális értékrendet (ismeretek, értékrend, szabályok), a szociális motívumokat (személyes kötődés, hovatartozás és egyebek), ill. a szociális képességeket (kommunikációs képességek, kontaktuskezelés, kötődés, segítés, együttmüködés, vezetés, versengés stb.) tartják számon. Részletesebb lebontásban: a kapcsolatfelvétel, a társas viszonyulás, a feladatvállalás, a feladattartás és az erkölcsi érzéket is idesorolják. (Nagy és mtsai, 2004). Kutatásunkban ez a felosztás képezte a kiindulópontot.

A szociális kompetencia óvodáskorban többféleképpen fejleszthető, a lehetőségek közül mi az élménypedagógiai tevékenységeket választottuk. Az élménypedagógia a tapasztalati tanulásból indul ki, a közvetlen, gyakorlati megtapasztalás, a konkrét helyzetek, a cselekvés általi tanulás egyik változata. Az élményalapú, élményközpontú tanulás napjainkra került elötérbe, amelynek során amikor a tanulás és a tevékenységek élményszerüségét hangsúlyozzuk, akkor az óvodások és a kisdiákok élményeire fókuszálunk (Földes és Peer, 2008). Az élményközpontú tanulásnak, tevékenységnek sokféle területe és fajtája ismeretes, mint ahogy az élménypedagógián belül is többféle irányvonal van jelen. Az élményközpontú tanulás, az élménypedagógiai tevékenységek során az óvodást, a tanulót az ismeretszerzési folyamat aktív, cselekvő részesévé tesszük, ahol magába a tevékenységbe olyan mértékben bevonódik, hogy megtapasztalja a cselekvés folyamatában létrejövő kompetencia élményét. Az élményközpontú tanulás, tevékenység vagy játék egyidejüleg tevékenységközpontú is, mivel a résztvevő óvodások, iskolások csakis aktív részvétellel tudják megtapasztalni az ún. kompetenciaélményt, a „képes vagyok megcsinálni”, az „ezt én csinálom” örömét (Péter, 2018). Óvodáskorban az élménypedagógiai tevékenységeket a 3-6 éves gyermekek életkori sajátosságaiból és szükségeleteiből kiindulva kell választanunk és szerveznünk. Ezeken a tevékenységeken a szabályok csupán keretet kézepnek, amelyben az óvodásoknak egyénileg vagy csoportosan kell megoldást találniuk a felvetett feladatra, vagy problémára. Így az élménypedagógiai tevékenységek, játékok folyamatában a saját tapasztalatok, a megélt élmények válnak tanulási helyzetté, tehát a cél nemcsak a tanulási élmény megszerzése, hanem a saját élményeken alapuló, cselekedtető tanulás is (Sztanáné Babics, 2020).

Az élményközpontú tevékenységek nagyon hatékonyak a különböző kompetenciák fejlesztésében, ugyanis amit közvetlenül, cselekvés által, a konkrét tevékenységbe bevonódva tapasztalunk meg, az mindig hatékonyabb és élményszerübb, mint a hagyományos tanulási formák és helyzetek. Az élménypedagógiai tevékenységek a kognitív képességek fejlesztésén túlmenően, a szociális kompetencia fejlesztéséhez is hozzájárulnak, így az önismeret, önértékelés, az egyéni felelősségvállalás, a tolerancia és egyéb szociális képességek alakításában is sikeresek. A továbbiakban a 4-6 éves óvodások szociális képességeinek élménypedagógiai tevékenységek és játékok általi fejlesztési lehetőségeit vizsgáljuk, egy általunk megvalósított empirikus kutatás bemutatásán keresztül.

\section{Kutatási probléma és hipotézisek}

A kutatás témája a 4-6 éves óvodás gyermekek szociális kompetenciájának fejlesztése az élménypedagógia játékainak, tevékenységeinek alkalmazásával. Az elméleti és gyakorlati tapasztalatok egyaránt arra utalnak, hogy sok kisiskolás, tinédzser és felnőtt is küzd szocialitással kapcsolatos problémákkal, sok esetben nehéz a kapcsolatteremtés, kommunikáció, egymásra figyelés, együttmüködés, empátia, tolerancia, egymás- és önelfogadás, társas és baráti kapcsolatok fenntartása Néhány ezirányú magyarországi kutatás arra világít rá, hogy a szociális kompetencia összetevőinek jelentős része óvodáskorban és kisiskoláskor elején zajlik, ugyanakkor a 4-8 éves gyermekek körében végzett DIFER-mérés (Nagy, Józsa, Vidákovich és Fazekasné, 2004) eredményei egyértelműen arra hívták fel a figyelmet, hogy jelentős eltérések 
vannak az azonos életkorúak szocialitása vonatkozásában. Szintén a szociális kompetencia fejlettségét megcélzó, 8-13 éves tanulókkal longitudinális kutatások eredményei arra utalnak, hogy a szociális kompetencia vonatkozásában alig mutatható ki spontán fejlődés, így e terület fejlesztését nem lehet a véletlenre bízni (Zsolnai és Józsa, 2003). Más nemzetközi kutatások eredményei arra is utalnak, hogy a szocializációs folyamatnak e korai időszakában kialakult szociális és érzelmi képességek, nemcsak az óvodai és iskolai életben hasznosak, hanem a felnőttkori élet eredményességére is hatással lehetnek (Chen, French és Schneider, 2006 idézi Péter, 2013, 115). A szociális képességek korai fejlesztésének jelentőségét felismerve foglalkoztunk a szociális képességei fejlesztésének lehetőségeivel a 4-6 éves óvodások körében. Kutatásunk célja az volt, hogy az általunk tervezett és megvalósított élménypedagógiai foglalkozások révén az óvodások minél több tapasztalatot szerezzenek a kapcsolatfelvétel, az együttmüködés, az együttes cselekvés és építő közös élmények vonatkozásában. Ennek megfelelően a kutatásunkban arra a kérdésre kerestük a választ, hogy az életkornak megfelelő élménypedagógiai tevékenységek és játékok alkalmazása milyen mértékben hatékony a 4-6 éves óvodások szociális képességeinek fejlesztésében? A kutatási problémánk alapján több hipotézist is megfogalmaztunk. Az alábbiakban azt a két hipotézist mutatjuk be, amelynek mentén vizsgálódunk.

1. Az élménypedagógiai játékokra és tevékenységekre építő fejlesztő beavatkozás következtében a 4-6 éves óvodások pozitív változást mutatnak a kapcsolatfelvétel terén.

2. A fejlesztö beavatkozás eredményeként az 4-6 éves óvodások pozitív változást mutatnak a társakhoz való viszonyulás terén.

A továbbiakban a hipotéziseink mentén vizsgálódunk.

\section{A kutatási minta}

Kutatásunk kétcsoportos kutatás, amelyben a mintavétel hozzáférés alapú. A kísérleti csoportot 24, a kontrollcsoportot 17 óvodás képezte. Demográfiai vonatkozásban, a kutatási minta mindkét csoportja átlagosnál jobbnak mondható, megfelelő szociális háttérrel rendelkezik. Az alábbiakban a kísérleti és kontroll csoportot a nem és életkor szempontjából hasonlítjuk össze.

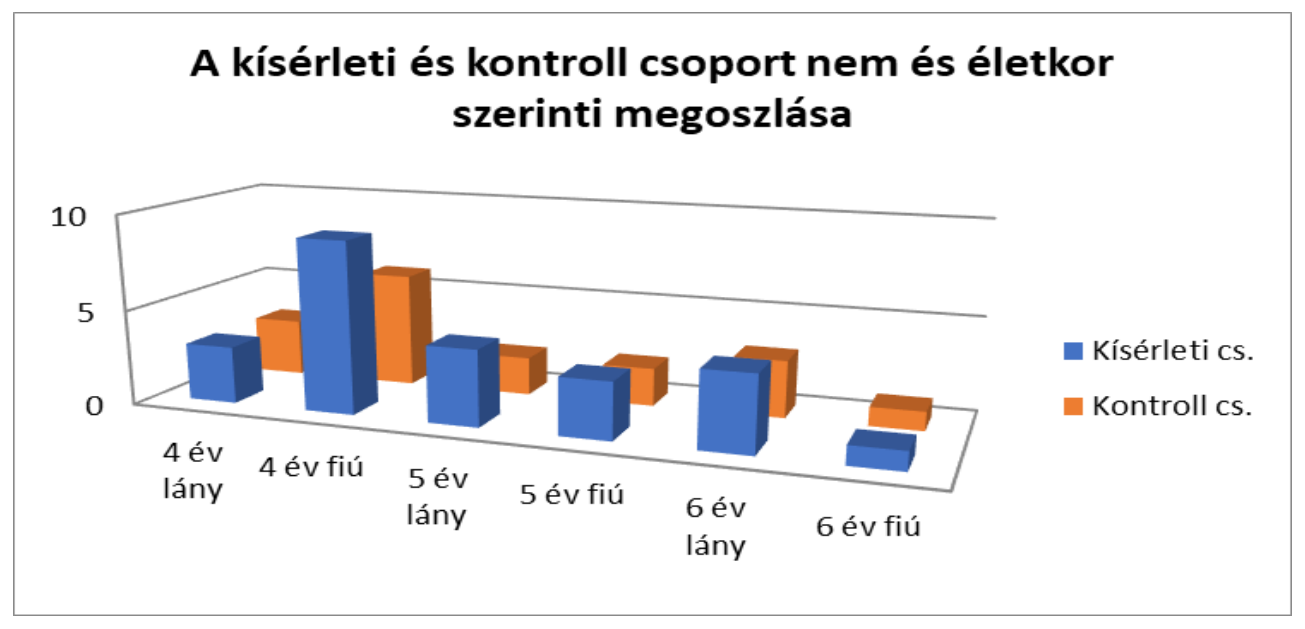

1. ábra. A kísérleti és kontroll csoport nem és életkor szerinti megoszlása

Amint a fentiekben is láthatjuk, bár a kísérleti és kontroll csoport között eltérés van a létszám vonatkozásában (24, illetve 17 óvodás), viszont ez a nemek aránya és az életkori megoszlás aránya szempontjából nem mondható jelentősnek. Mindkét csoportban a fiúk és a 4 évesek aránya a magasabb. Tehát ilyen vonatkozásban a kísérleti és kontroll csoport összetétele hasonlónak mondható. Továbbá a 24 és 17 gyermekmindegyike megfelelő szociális háttérrel rendelkezik, viszonylag jó anyagi körülmények között, ép családban nevelkedik. Szándékosan választottunk a 
kísérleti csoporthoz több demográfiai vonatkozásban is hasonló kontroll csoportot, hogy az összehasonlítás minél reálisabb legyen. A kísérleti csoport napközis, a kontroll csoport pedig rövid programú óvoda keretei között működik. A szociális képességek fejlődését meghatározó tényezők közül a társadalmi (kulturális, gazdasági, makro- és mikroszociális) tényezők, továbbá a hasonló összetételnek köszönhetően a kortárscsoportok szerepe is hasonlóan befolyásolja az említett képességek fejlődését. A családi tényezőket tekintve is hasonlóságot tapasztalunk. Mindenik gyermek mindkét csoport esetében a családszerkezetre vonatkoztatva ép családban él (nem elvált szülök gyermekei), viszont mindkét csoport esetében gyakori az édesapa külföldi munkavállalása. Továbbá minden gyermeknek van testvére, és a nagyszülők is részt vállalnak a gyermekek nevelésében. Az óvoda mint másodlagos szocializációs háttér nem torzítja az eredményeket, mindkét csoport ugyanabban az óvodában található. Jelentős különbségek az egyéni képességekben és személyes lehetőségekben, az anya-gyermek kötődésében lehetnek, de ezek a különbségek már a preteszt elvégzésekor hatással vannak az eredményekre, így valószínü, hogy a posztteszt eredményeit nem befolyásolják eltérő módon.

\section{A kutatás menete, kutatási módszer és eszköz}

Mivel kutatási stratégiánk a kétcsoportos kísérlet volt, így a kutatás három lépésben zajlott. Így a kutatás kezdetén, a beavatkozás előtt a DIFER teszttel (Nagy és mtsai, 2004) mértük fel (preteszt) a kísérleti és kontroll csoport óvodásait a szocialitással kapcsolatos területek mentén. Ezt követte a 15 hetes fejlesztő beavatkozás a kísérleti csoportban, majd utána a posztteszt következett, amelynek során ismét felmértük mindkét csoport óvodásait. A fejlesztő beavatkozás időtartama 15 hét volt, amelynek során mindennap alkalmaztunk legalább egyszer élménypedagógiai játékot, amelyet a tapasztalati területek szerinti tevékenységekbe (TTT), a reggeli beszélgetőkörbe és a szabadon választható tevékenységekbe (SZVT) építettünk be. A táblázatban a fejlesztő beavatkozásunkat foglaltuk össze (1. táblázat).

1. táblázat. A fejlesztő beavatkozás programja

\begin{tabular}{|l|l|l|l|}
\hline Idópont & Játéktípus & Fejlesztett terület & Példák \\
\hline 1. hét & Ismerkedést segítő játékok & $\begin{array}{l}\text { - ismerkedés elösegítése } \\
\text { - kapcsolatfelvétel } \\
\text { képességének fejlesztése }\end{array}$ & $\begin{array}{l}\text { Puzzle } \\
\text { Csetepaté }\end{array}$ \\
\hline 2. hét & Csoportalakító játékok & csoportalakítás & $\begin{array}{l}\text { Tedd karba a kezed! Ide } \\
\text { áll, oda áll! Hánykor } \\
\text { keltél? ... }\end{array}$ \\
\hline 3. hét & Csapatépítő játékok & $\begin{array}{l}\text { - csapatépítés } \\
\text { - kapcsolatfelvétel, } \\
\text { kapcsolattartás fejlesztése } \\
\text { - feladattartás fejlesztése }\end{array}$ & A varázsló erdeje \\
\hline 4. hét & $\begin{array}{l}\text { Feloldódás segítését célzó } \\
\text { játékok }\end{array}$ & $\begin{array}{l}\text { - vállalkozói képesség } \\
\text { fejlesztése }\end{array}$ & Hettyen pitty \\
\hline 5. hét & $\begin{array}{l}\text { Bemelegító, ráhangoló } \\
\text { játékok }\end{array}$ & $\begin{array}{l}\text { - bemelegítés, koncentráció } \\
\text { fejlesztése }\end{array}$ & Jork \\
\hline 6. hét & Együttmüködési játékok & - együttmüködési, & Fogadj be! \\
\hline
\end{tabular}




\begin{tabular}{|c|c|c|c|}
\hline & & $\begin{array}{l}\text { közösségfejlesztő } \\
\text { - egymásra figyelés, egymás } \\
\text { elfogadása }\end{array}$ & \\
\hline 7. hét & Csapatmunka fejlesztése & $\begin{array}{l}\text { - együttmüködési képesség, } \\
\text { csapatmunka fejlesztése }\end{array}$ & $\begin{array}{l}\text { Ejtőernyő } \\
\text { Add tovább a kört! } \\
\text { Csetepaté }\end{array}$ \\
\hline 8. hét & Mozgásos játékok & $\begin{array}{l}\text { - együttmúködés, stratégiai } \\
\text { érzék fejlesztése } \\
\text { - egymásra figyelés } \\
\text { - kreativitás }\end{array}$ & $\begin{array}{l}\text { Szalagháború } \\
\text { Szoborválasz } \\
\text { A varázsló erdeje }\end{array}$ \\
\hline 9. hét & $\begin{array}{l}\text { Kommunikációfejlesztő, } \\
\text { konszenzuskereső }\end{array}$ & $\begin{array}{l}\text {-problémamegoldó képesség } \\
\text { - kommunikációs képesség } \\
\text { - együttmüködési képesség }\end{array}$ & A recepciós \\
\hline 10. hét & $\begin{array}{l}\text { Figyelemfejlesztő, } \\
\text { élénkítő }\end{array}$ & $\begin{array}{l}\text { - figyelem } \\
\text { - élénkítés }\end{array}$ & Helycsere \\
\hline 11. hét & $\begin{array}{l}\text { Játékok az élmények, } \\
\text { történések felidézéséhez }\end{array}$ & - erkölcsi ítélöképesség & Érzelemkártyák \\
\hline 12. hét & Energetizáló játékok & $\begin{array}{l}\text { - kapcsolatfelvétel, } \\
\text { kapcsolattartás }\end{array}$ & $\begin{array}{l}\text { Szalagháború } \\
\text { Kész cirkusz }\end{array}$ \\
\hline 13. hét & Bizalomfejlesztő & $\begin{array}{l}\text { - bizalom } \\
\text { - kommunikáció } \\
\text { - feladattartás }\end{array}$ & Cipőhalom \\
\hline 14. hét & Ügyességi & $\begin{array}{l}\text { - ügyesség, feladattartás } \\
\text { - kapcsolatfelvétel, } \\
\text { kapcsolattartás } \\
\text { - vállalkozói képesség }\end{array}$ & $\begin{array}{l}\text { Kioltós } \\
\text { Gyüjts embert! } \\
\text { Bökdösős }\end{array}$ \\
\hline 15. hét & Szellemi, logikai játékok & $\begin{array}{l}\text { - megfigyelőképesség } \\
\text { koncentrációs képesség } \\
\text { - feladattartás }\end{array}$ & $\begin{array}{l}\text { Képeslap-memory } \\
\text { Kérdésautomata }\end{array}$ \\
\hline
\end{tabular}

A megfelelő élménypedagógiai játék kiválasztásakor több szempontot is figyelembe vettünk. Így a kutatási céljainkat, a játékok típusát, az óvodások életkorát és elözetes tapasztalatait, a csoport aznapi létszámát, a hely és idő feltételeit vettük figyelembe. A játékok kiválasztásánál az egyik legfontosabb szempont az volt, hogy elnyerje az óvodások tetszését, hiszen csak így érvényesülhetnek az élménypedagógiai tevékenységek hatásai. A játéktípusok vonatkozásában a játékok célja lehet például koncentráció erősítése, szórakoztatás, energetizálás, tanítás, ismétlés, csapatépítés. A játékok nehézségi fokára is igyekeztünk kellő figyelmet fordítani, hiszen, ha nagyon nehéz, akkor kudarcként élhetik meg az óvodások, ha túl könnyü a játék, akkor elveszthetik motiváltságukat, unalmassá válhat számukra. A fejlesztő beavatkozás játékainak a kiválasztásakor a szociális kompetencia fejlesztését tartottuk leginkább szem előtt, így azokat az 
élménypedagógiai játékokat, tevékenységeket helyeztük előtérbe, amelyek a szociális kompetencia fejlesztésében lehetnek sikeresek. Így kapcsolatfelvételt és -tartást, csoportalakító, együttmüködést, kommunikációs, vállalkozói képességet, erkölcsi ítélőképességet fejlesztő és közösségformáló játékokat egyaránt alkalmaztunk. A fejlesztő programot a reggeli beszélgetőkörbe, közös tevékenységbe, szabad tevékenységekbe, délutáni tevékenységekbe építettük be. Olyan gyakorlatokat, játékokat válogattunk össze az élménypedagógia játékai közül, melyek elvégzése által szociális magatartásuk pozitív irányba történő változását váruk. A feladatokat, játékokat részben átdolgoztuk, a gyermekek életkori sajátosságait figyelembe véve. A gyakorlatok, feladatok, játékok elvégzésének célja volt, hogy fejlesszék az önismeretet, társak ismeretét, kapcsolattartást, bizalmat, együttmüködést, empátiát, szabályok megértését és fejlesztését, érzelmek megértését és kifejezését. Szükség esetén a betervezett tevékenységeken kívül is minden alkalmat megragadtunk a fejlesztésre, így például az étkezés, öltözködés, séták, egymás közötti kisebb-nagyobb problémák, konfliktusok alkalmával. Hetente egy-egy terület fejlesztését céloztuk meg, a megfelelő játékos gyakorlatok, feladatok alkalmazásával, de minden lehetséges alkalmat megragadtunk ezen kívül a heti téma gyakorlására. A fejlesztő program során a csoportban kevésbé népszerü gyermekek szocializációjának segítését is szem elött tartottuk. A kísérleti csoport óvodásai nagy örömmel kapcsolódtak be a tevékenységekbe, nyitottak, elfogadóak voltak, minden fejlesztő tevékenység örömet jelentett számukra, nagyon jól érezték magukat.

Amint már említettük a kutatási stratégiánk a kétcsoportos kísérlet volt, amelybe a 4-6 éves óvodások szocialitás területein való elő- és utófelmérése, illetve az élménypedagógiai játékokat és tevékenységeket alkalmazó fejlesztő program épült be. Kutatási eszközként a DIFER (Diagnosztikus fejlődésvizsgáló rendszer 4-8 évesek számára), standardizált tesztet alkalmaztuk. A DIFER programcsomag (Nagy és mtsai, 2004) az eredményes iskolakezdéshez szükséges hét kritikus elemi készséget és képességet méri, amelyek közül mi, a kutatási céljainknak megfelelően, a szocialitással kapcsolatos területeket vizsgáló részeit (altesztjeit) alkalmaztuk. Ennek megfelelően az elő- és utófelméréskor, a társakhoz való viszonyulás, a kapcsolatfelvétel, a vállalkozói képesség, a feladattartás és az erkölcsi ítélőképesség (erkölcsi érzék) területek mindegyike mentén felmértül az kutatásban részt vevő óvodásokat. Mivel jelen tanulmány keretei között nincs módunk a teljes kutatás bemutatására, így most a felmért területek közül csak a társakhoz való viszonyulás és a kapcsolatfelvétel területei mentén vizsgálódunk.

\section{A kutatási eredmények bemutatása és értelmezése}

Az elő- és utófelmérés eredményeinek összehasonlítása, a hipotéziseink mentén való vizsgálódást, fejlesztőprogramunk hatékonyságának bizonyítására adott lehetőséget.

\subsection{A kapcsolatfelvétel képességének változása}

Az első hipotézisünkben az élménypedagógiai játékokra és tevékenységekre építő fejlesztő beavatkozás következtében a 4-6 éves óvodások kapcsolatfelvétel képességének a változását feltételeztük. Az elö- és utófelmérés eredményeit összehasonlítva azt láthatjuk, hogy a kísérleti csoportnál jelentős változás következett be. 


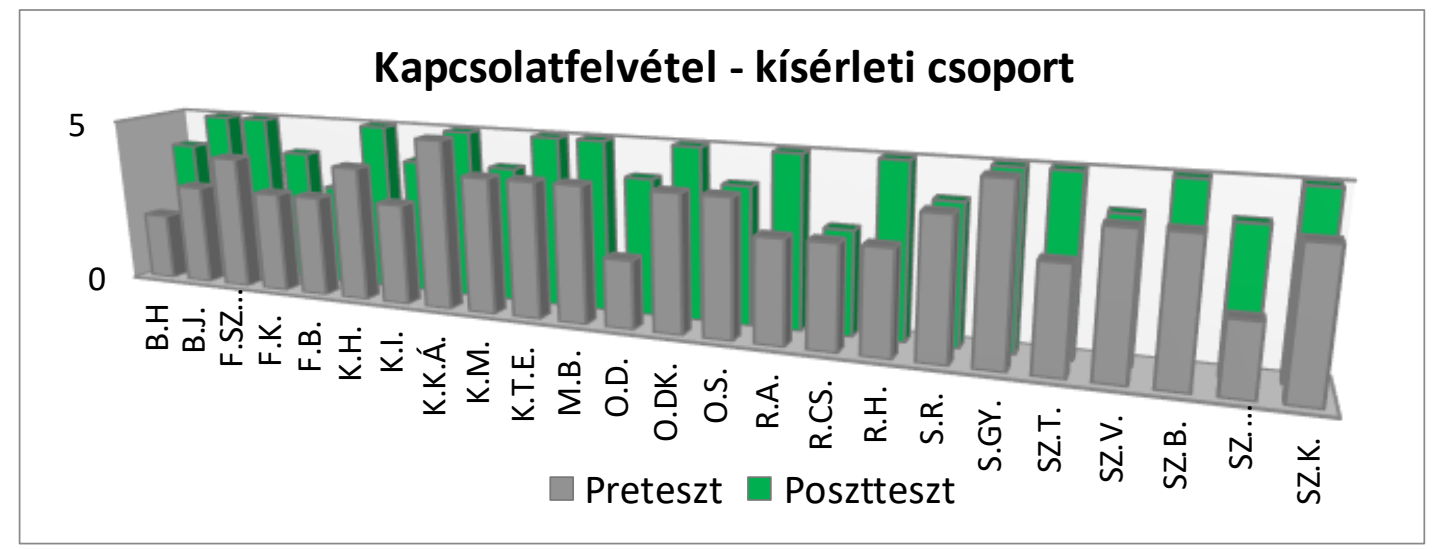

2. ábra. Kapcsolatfelvétel szintjének összehasonlítása az elö- és utófelmérés alapján a

kísérleti csoportnál

A kapcsolatfelvétel vizsgálata során azt is láthattuk, hogy a kísérleti csoportban már az induláskor magasabb értékek voltak, több óvodásnak is már induláskor könnyedén teremtett kapcsolatot (11 óvodás), és csupán 2 gyermek volt, akik alacsony szinten voltak induláskor (2 pontot értek el). A kapcsolatfelvétel alakulásának statisztikai vizsgálata az alábbi táblázatban van összegezve.

2. táblázat. Kapcsolatfelvétel változása a kísérleti csoport esetében

\begin{tabular}{|l|l|l|l|l|l|}
\hline \multirow{2}{*}{$\begin{array}{l}\text { Kapcsolatfelvétel vizsgálata a } \\
\text { kísérleti csoport esetében }\end{array}$} & & Átlag & Szórás & t- érték & Szignifikancia \\
\cline { 2 - 6 } & Preteszt & 3,50 & 0,834 & 6,23 & \multirow{2}{*}{0,005} \\
\cline { 2 - 6 } & Posztteszt & 4,58 & 0,658 & & \\
\hline
\end{tabular}

A t-érték és a szignifikanciaszint arra mutat rá, hogy a kísérleti csoport esetében az élménypedagógiai játékok és tevékenységek alkalmazása sikeres volt, ugyanis az elő- és utófelmérés eredményei között szignifikáns változás $(\mathrm{p} \leq 0,005)$ mutatható ki.

A kontroll csoport eredményeit vizsgálva azt tapasztaltuk, hogy itt is már indulásból jók voltak a kapcsolatfelvétel eredményei, azonban az óvodások közül többnél is stagnálás, vagy visszafejlődés figyelhető meg. Tehát ez is alátámasztja azt a szakirodalmi megállapítást, amely szerint a szociális kompetencia vonatkozásában alig mutatható ki spontán fejlődés (Zsolnai és Józsa, 2003). Az egyes gyermekek szintjén tapasztalt változást az alábbi ábrán foglaljuk össze. 


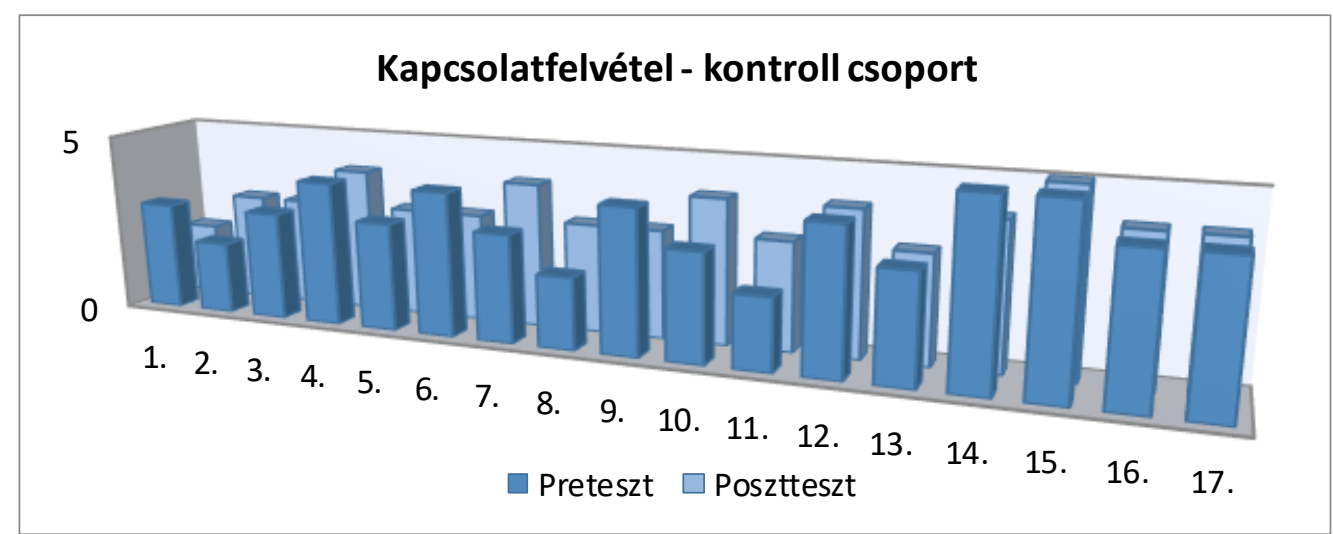

3. ábra. Kapcsolatfelvétel szintjének összehasonlítása az elő- és utófelmérés alapján a kontroll csoportnál

Ha az egyes gyermekek kapcsolatteremtését vizsgáljuk, akkor azt látjuk, hogy néhányan egy kevéssel jobb eredményt értek el az utófelmérésnél, amíg mások az utófelmérésnél gyengébb eredményt értek el. A kapcsolatfelvétel elö- és utófelmérés eredményeinek statisztikai vizsgálata nem mutatott ki szignifikáns változást (3. táblázat).

3. táblázat. Kapcsolatfelvétel vizsgálata a kontroll csoport esetében

\begin{tabular}{|l|l|l|l|l|l|}
\hline \multirow{2}{*}{$\begin{array}{l}\text { Kapcsolatfelvétel vizsgálata } \\
\text { a kontroll csoport esetében }\end{array}$} & & Átlag & Szórás & t- érték & Szignifikancia \\
\cline { 2 - 5 } & Preteszt & 3,41 & 0,939 & 0,74 & $\begin{array}{l}\text { Nem } \\
\text { mutatható ki }\end{array}$ \\
\cline { 2 - 5 } & Posztteszt & 3,47 & 0,717 & & \\
\hline
\end{tabular}

Tehát a kontroll csoportban az adott időszakban nem volt megfigyelhető releváns fejlődés. Ha a kísérleti és kontroll csoport eredményeit hasonlítjuk össze a kapcsolatfelvétel terén, akkor azt látjuk, hogy az utófelméréskor jelentős különbség van a két csoport óvodásainak kapcsolatfelvétele között (4. ábra). 


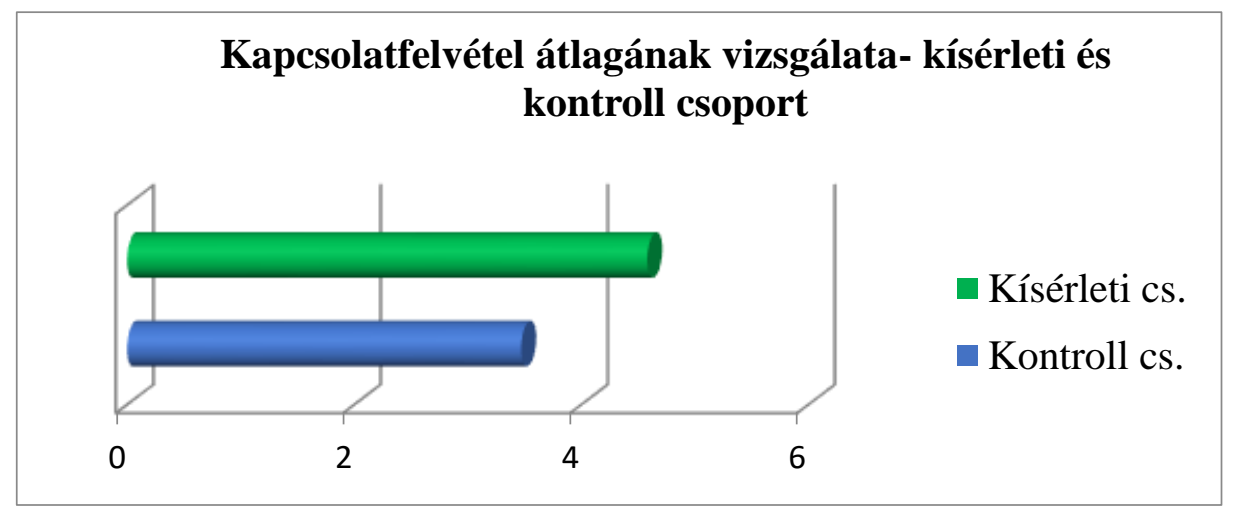

4. ábra. Kapcsolatfelvétel átlagának összehasonlítása a kísérleti és kontroll csoport esetében

A kísérleti csoport esetében magasabb pontszámok figyelhetőek meg, föleg ha szem előtt tartjuk azt is, hogy hasonló átlagról indult a két csoport, a kísérleti csoport 3,50-ről, a kontroll csoport ez 3,41 pont volt. Ezek az értékek 4,58-ra és 3,47-re változtak a posztteszt elvégzésekor. Tehát a kísérleti csoport óvodásai, a kapcsolatfelvételt vonatkozásában sikeresebbnek bizonyultak, mint a kontroll csoport óvodásai. Ezt a statisztikai adatok is bizonyítják, mivel a két csoport átlagának különbsége szignifikáns $(\mathrm{p}=0,005)$. A kapcsolatfelvétellel kapcsolatos hipotézisünk beigazolódott, az élménypedagógiai tevékenységek hatékonynak bizonyultak a 4-6 éves óvodások kapcsolatfelvételi képességének fejlődésében.

\subsection{A társakhoz való viszonyulás képességének változása}

A második hipotézisünkben azt feltételeztük, hogy az élménypedagógiai játékokra és tevékenységekre építő fejlesztő beavatkozás eredményeként 4-6 éves óvodásoknál pozitív változást figyelhetünk meg a társakhoz való viszonyulás terén. A társas kapcsolatokat, a társakhoz való viszonyulást - a DIFER teszt szempontrendszerének megfelelően - az óvodások együttmüködést igénylö, csoportos feladat teljesítése közben mértük fel. Ezek a tevékenységek a heti téma és a fejlesztő beavatkozás témáinak összehangolása során jöttek létre. Az alábbiakban ezeket az eredményeket elemezzük. A kísérleti csoport vonatkozásában az elő- és utófelmérés eredményeit összehasonlítva majdnem mindegyik óvodásnál növekedést figyelhettünk meg (5. ábra).

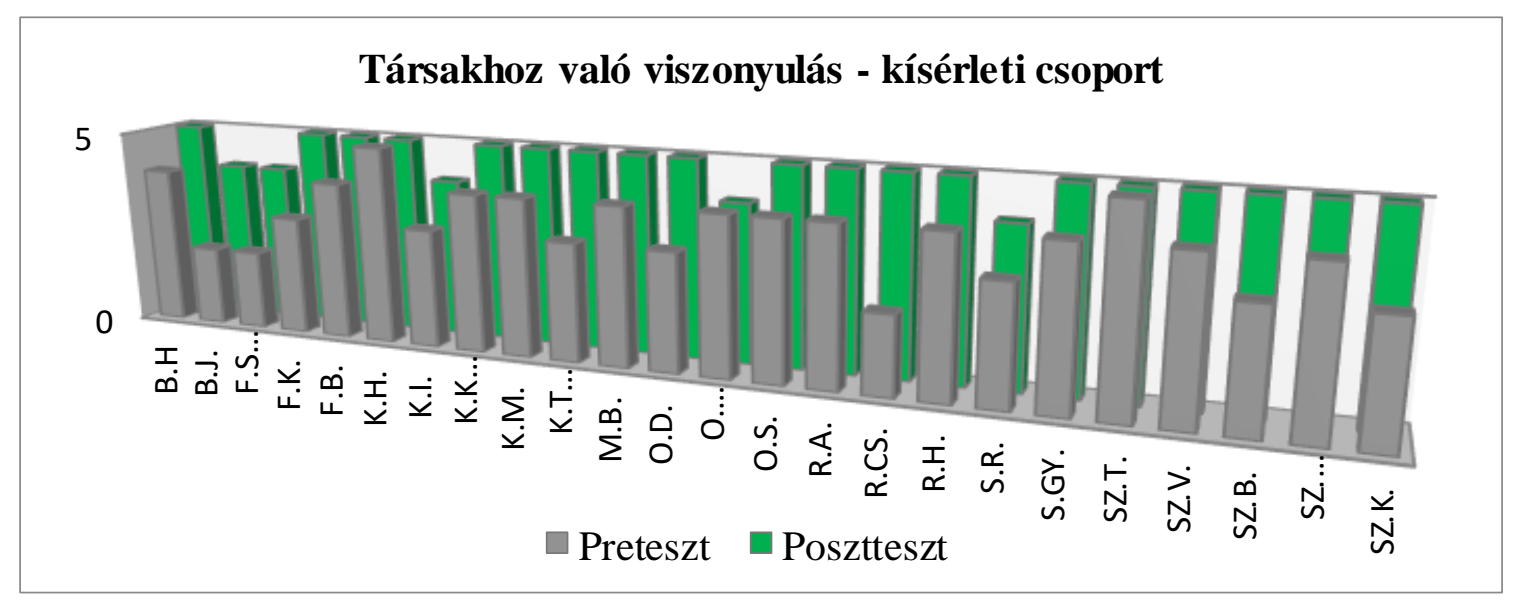

5. ábra. Társakhoz való viszonyulás képességének alakulása a kísérleti csoport esetében 
Ahogy az ábrán láthatjuk, a posztteszt értékei mindegyik gyereknél magasabbak, mint preteszt értékei. Az előfelmérésnél három gyermek mutatta a legalacsonyabb szintet, szinte zavaró volt a magatartásuk. Ehhez képest, a fejlesztés végére, kettő közülük a társakhoz való viszonyulás szempontjából sokat fejlődött, ugyanis 4-4 pontot értek el. Úgy gondoljuk, hogy ez nagy fejlődést és hatalmas előrelépést jelent a csoport életében, és ez a munkavégzés közbeni csoporthangulaton is érezhető volt, vagyis sokkal kevésbé zavarták egymást és jobban együttmüködtek a gyerekek. Az elö- és utófelmérés eredményeinek összehasonlítása jelentős különbségről tanúskodik (4. táblázat).

4. táblázat. Társakhoz való viszonyulás vizsgálata a kísérleti csoport esetében

\begin{tabular}{|l|l|l|l|l|l|}
\hline \multirow{2}{*}{$\begin{array}{l}\text { Társakhoz való viszonyulás } \\
\text { vizsgálata a kísérleti csoport } \\
\text { esetében }\end{array}$} & Átlag & Szórás & t- érték & Szignifikancia \\
\cline { 2 - 6 } & Preteszt & 3,54 & 0,832 & 2,326 & 0,025 \\
\cline { 2 - 5 } & Posztteszt & 4,79 & 0,414 & & \\
\hline
\end{tabular}

A kísérleti csoport adatainak statisztikai összehasonlítása jelentős, vagyis szignifikáns $(p=0,02)$ változást mutat, és ez a fejlesztő beavatkozás sikerességét bizonyítja.

A társakhoz való viszonyulás változását a kontroll csoport esetében is vizsgáltuk, amelynek az eredményeiről az alábbiakban számolunk be (5. ábra).

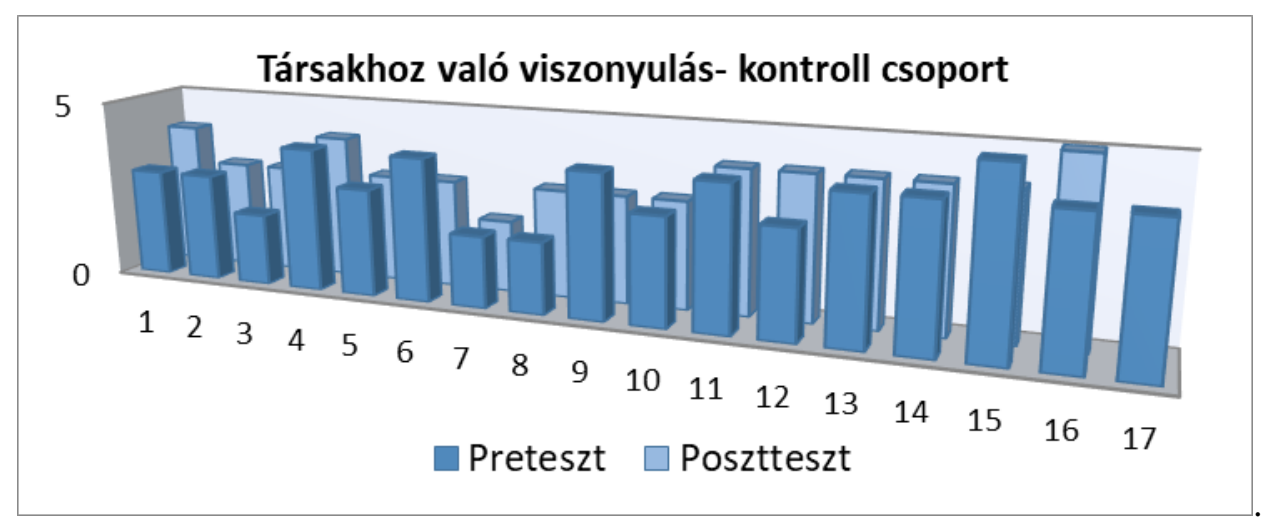

6. ábra. Társakhoz való viszonyulás változása a kontroll csoport óvodásainál

A fenti ábrán láthatjuk, hogy a kontroll csoport óvodásainál már induláskor alacsonyabb pontértékek voltak. Ezeket az adatokat nem elemezzük alaposan, viszont könnyen kivehető, hogy 5 gyereknél mutatható ki spontán fejlődés a kapcsolatfelvétel terén, 7 gyermek ugyanazon a szinten maradt, és 4 gyereknél visszafejlődés figyelhető meg.

5. táblázat. Társakhoz való viszonyulás változása a kontroll csoport esetében

\begin{tabular}{|l|l|l|l|l|l|}
\hline \multirow{2}{*}{$\begin{array}{c}\text { Társakhoz való viszonyulás } \\
\text { vizsgálata a kontroll csoport }\end{array}$} & & Átlag & Szórás & t- érték & Szignifikancia \\
\cline { 2 - 7 } & Preteszt & 3,41 & 0,870 & 0,749 & 0,20 \\
\hline
\end{tabular}




\begin{tabular}{|l|l|l|l|l|l|}
\hline esetében & Posztteszt & 3,47 & 0,717 & & \\
\hline
\end{tabular}

Bár a kontroll csoport óvodásainál is bekövetkezett minimális szintü növekedés, viszont az adatok statisztikai elemzése nyomán egyértelmü, hogy ez nem szignifikáns $(\mathrm{p}=0,2)$.

Ha a kísérleti és kontroll csoport társakhoz való viszonyulásának a fejlődését hasonlítjuk össze, akkor egyértelmü, hogy a kísérleti csoport óvodásai számottevően sikeresebbnek bizonyultak a társakhoz való viszonyulás terén, mint a kontroll csoport óvodásai.

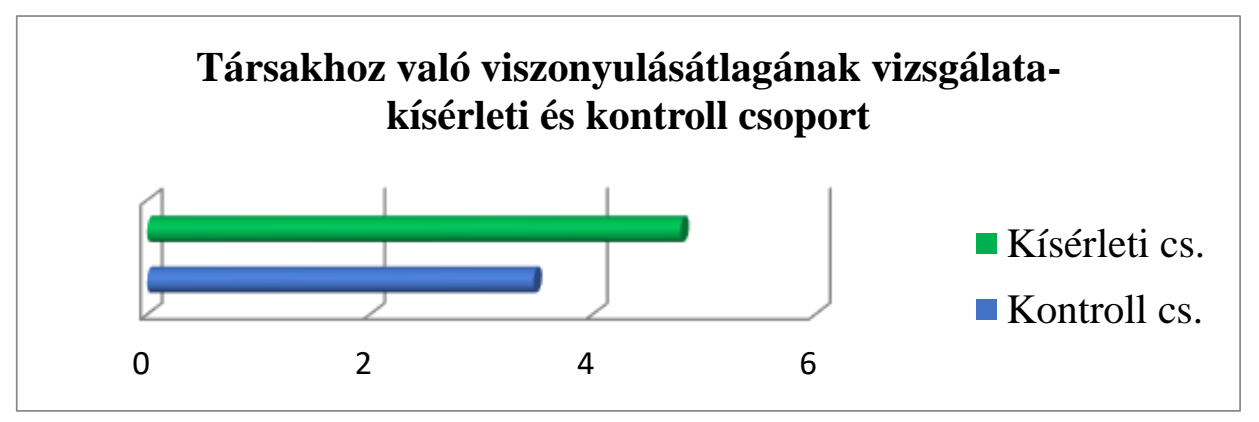

7. ábra. Társakhoz való viszonyulás átlagának vizsgálata a kísérleti és kontroll csoport esetében

Az eredmények statisztikai összehasonlítása alapján a két csoport utófelmérésének átlageredménye (kísérleti csoport átlaga 4,79, a kontroll csoport átlaga 3,47) között szignifikáns különbséget állapíthatunk meg $(\mathrm{P}=0,005)$. Tehát a társakhoz való viszonyulással kapcsolatos hipotézisünk is beigazolódott, vagyis az élménypedagógiai játékok és tevékenységek alkalmazásának köszönhetően a 4-6 éves óvodások esetében jelentős fejlödés mutatkozott meg a társakhoz való viszonyulás terén is.

\section{Összegzés}

Kutatásunkban az élménypedagógiai játékok és tevékenységek hatékonyságát vizsgáltuk 4-6 éves óvodások körében. Kutatásunkban a szociális képességek több területére is kiterjedt a vizsgálatunk, jelen tanulmány keretei között a társakkal való kapcsolatfelvétel és a társakhoz való viszonyulás vonatkozásában vizsgálódtunk. E két területhez kötődő hipotéziseink beigazolódtak, tehát egyértelmủen kijelenthetjük, hogy az élménypedagógiai játékok és tevékenységek hatékonyak lehetnek az óvodások szociális képességeinek, konkrétan a társakkal való kapcsolatfelvétel és a társakhoz való viszonyulás fejlődése vonatkozásában.

Azt tényként fogadhatjuk el, hogy a szociális képességek alakulásában a családnak van elsődleges szerepe, viszont az óvoda mint másodlagos szocializációs színtér is jelentős mértékben hozzájárul ennek alakulásához. Hiszen a gyermekóvodába kerülésével számára a szociális tér kitágul, az óvodai csoport az első közösség, ahová be kell illeszkednie, a pedagógus és a társakkal való kapcsolatok által gyakorolják a társas képességeiket, fejlődik szociális kompetenciájuk.

A fejlesztő beavatkozás során és utána, örömmel tapasztaltuk azt, hogy a megcélzott szociális képességek fejlesztésén túlmenően más pozitív eredmények is jelentkeztek a kísérleti csoport óvodásainál. A beavatkozás után az óvodások: jobban figyeltek és vigyáztak egymásra, több empátiával viszonyultak egymáshoz, jobban alkalmazkodtak egymáshoz és helyzetekhez, szívesen kértek és nyújtottak segítséget. Ezek mind fontos tapasztalatok, amelyek nemcsak hasznosak, hanem adott esetben további kutatás tárgyát képezheti. 
Mivel az óvodapedagógusok fontos feladata, egyéb területek mellett az, hogy a gyermekek szociális képességeinek a fejlesztésére is hangsúlyt helyezzen, és hogy óvodáskor végéig, iskoláskor elejéig, minél több gyermek elérje az optimális fejlettségi szintet ezen a területen is. Mivel fejlesztő beavatkozásunk sok örömteli pillanatot szerzett számunkra, ugyanakkor nagyon hasznosnak is bizonyult, ezért bátran ajánljuk minden óvodapedagógusnak az élménypedagógiai játékok és tevékenységek alkalmazását.

\section{Irodalomjegyzék:}

Földes P., Peer K. (2008): Alkotva tanulunk. Tevékenységközpontú foglalkozások 11-12 éveseknek. Dinasztia Tankönyvkiadó, Budapest.

Konta I, Zsolnai A. (2002): A szociális készségek játékos fejlesztése az iskolában. Nemzeti Takönyvkiadó, Budapest

Lazsádi Cs. (2017): A mikroszociális tényezők hatása a szociális kompetencia fejlödésére óvodáskorban. Kolozsvári Egyetemi Kiadó, Kolozsvár

Nagy J. (2000): XXI. század és nevelés. Osiris Kiadó, Budapest.

Nagy J., Józsa K, Vidákovich T, Fazekasné Fenyvesi M. (2004): Difer Programcsomag. Diagnosztikus fejlödésvizsgáló rendszer 4-8 évesek számára. Mozaik Kiadó, Szeged

Péter L. (2013): „Arra taníts, hogy önálló lehessek, hogy büszke lehessek magamra!” - Az erkölcsi fejlesztés szükségessége és lehetőségei kisiskoláskorban. In. Dósa Z. (szerk.): Kompetencia- és tudástranszfer az oktatásban. Az V. tudományos ülésszak elöadásai, Kolozsvári Egyetemi Kiadó, Kolozsvár, 115-129.

Péter L. (2018): Örömteli tanulás? Az élményközpontú tanulás tanórai lehetőségeiröl. In Barabási T., Péter L, Szántó B. (szerk.): Kompetencia- és tudástranszfer az oktatásban. A IX. tudományos ülésszak előadásai, Kolozsvári Egyetemi Kiadó, Kolozsvár, 35-48.

Tóth E., Kasik L. (2010): A szociális kompetencia fejlesztésének főbb koncepciói és a pedagógusok szerepe a fejlesztésben. In: Zsolnai A, Kasik L. (szerk.): A szociális kompetencia fejlesztésének elméleti és gyakorlati alapjai. Nemzeti Tankönyvkiadó, Budapest, 163-179.

Sztanáné Babics E. (2020): Élménypedagógia az óvodában, élménypedagógia a képzésben. In: Bíró V. (szerk.): Befogadó iskola, befogadó óvoda. Eötvös József Főiskolai Kiadó, Baja, 23-32.

Zsolnai A, Józsa K. (2002): A szociális készségek kritériumorientált fejlesztésének lehetőségei. Iskolakultúra 12/4, 12-20.

Zsolnai A, Józsa K. (2003): A szociális készségek fejlesztése kisiskoláskorban. In Zsolnai A. (szerk.): Szociális kompetencia - társas viselkedés. Gondolat Kiadó, Budapest, 205-227.

Zsolnai A. (2010): A szociális kompetencia kutatására és fejlesztésére szolgáló modellek. In: Zsolnai A., Kasik L. (szerk.): A szociális kompetencia fejlesztésének elméleti és gyakorlati alapjai. Nemzeti Tankönyvkiadó, 2010, 78-96.

\section{Szerzők:}

Kovács Réka Mária, Zöld Péter Általános Iskola, Micimackó Napköziotthon, Csíkmadéfalva, Románia, kkovacsreka04@gmail.com

Péter Lilla, Babes-Bolyai Tudományegyetem, Pszichológia és Neveléstudományok Kar, Pedagógia és Alkalmazott Didaktika Intézet, Székelyudvarhelyi Kihelyezett Tagozat, Románia, peter.lilla@gmail.com 